\title{
Efek Staebler-Wronski dan Pengaruh Waktu Anil pada Lapisan Instrinsik Silikon Amorf Terhidrogenasi (a-Si:H)
}

\author{
Yoyok Cahyono, ${ }^{*}$ Fuad D. Muttaqin, Umi Maslakah, Malik A. Baqiya, \\ Mochamad Zainuri, Eddy Yahya, Suminar Pratapa, dan Darminto \\ Departemen Fisika-FMIPA, Institut Teknologi Sepuluh Nopember(ITS), Kampus ITS, Sukolilo, Surabaya, 60111
}

\begin{abstract}
Intisari
Silikon amorf terhidrogenasi (a-Si:H) adalah salah satu material sel surya yang sangat menjanjikan, karena jika dibandingkan dengan kristal silikon (c-Si) material ini mempunyai absorpsivitas yang lebih besar dengan kebutuhan material yang lebih sedikit (tipis). Sehingga diharapkan dapat mereduksi biaya produksi dan harga sel surya. Tetapi sampai saat ini masih banyak persoalan yang belum terselesaikan, terutama yang berkaitan dengan efisiensi yang masih rendah, dan efek Staebler-Wronski. Penelitian ini bertujuan untuk mempelajari efek Staebler-Wronski, yaitu pengaruh lama waktu paparan panas pada lapisan material sel surya dengan menggunakan cara perlakuan anil. Hasil penelitian menunjukkan bahwa semakin lama waktu anil, ada kecenderungan untuk menurunkan transmitansi, yang diperkirakan disebabkan oleh perubahan kristalinitas, celah pita energi, energi Urbach dan ukuran partikel. Kenaikan waktu anil dapat mengakibatkan terlepasnya ikatan hidrogen yang menyebabkan terjadinya peningkatan keadaan terlokalisasi, karena aktivasi ikatan lepas, dan ikatan lepas inilah penyebab utama terjadinya efek Staebler-Wronski.
\end{abstract}

\section{ABSTRACT}

\begin{abstract}
Hydrogenated amorphous silicon (a-Si:H) is one of the most promising solar cell materials, as compared to the crystalline silicon (c-Si). This material has a greater absorption with thinner material requirement. So it is expected to reduce the cost of production and price of solar cells. However, until now there are still many unresolved issues, especially with regard to low efficiency, and the Staebler-Wronski effect. This study aims to describe the effect of Staebler-Wronski, which is the effect of long-time exposure to heat on the layer of solar cell material by means of annealing treatment. The results show that the longer annealing time, there is a tendency to decrease transmittance, which is thought to be caused by changes in crystallinity, energy band gap, Urbach energy and particle size. The increasing annealing time can lead to the release of hydrogen bonds that cause an increase in localized state, due to the activation of the dangling bond which is the main cause of the Staebler-Wronski effect.
\end{abstract}

KATA KUNCI: efek Staebler-Wronski, waktu anil, lapisan instrinsik, a-Si:H http://dx.doi.org/10.12962/j24604682.v13i2.2299

\section{PENDAHULUAN}

Sejak sel surya berbasis silikon amorf terhidrogenasi (a$\mathrm{Si}: \mathrm{H})$ pertama kali dibuat oleh Carlson dan Wronski pada tahun 1976, penelitian dan pengembangan tentang sel surya ini telah banyak dilakukan [1]. Ditinjau dari sisi untuk mereduksi biaya produksi dan harga material a-Si:H ini sangat menjanjikan, karena mempunyai absorpsivitas yang lebih besar dengan kebutuhan material yang lebih sedikit (tipis) jika dibandingkan dengan kristal silikon (c-Si). Tetapi sampai saat ini masih banyak persoalan yang belum sepenuhnya terselesaikan, terutama yang berkaitan dengan efisiensi yang masih rendah, dengan hasil penelitian terbaik yang dilakukan oleh NREL (National Renewable Energy Laboratory) baru mencapai $13,4 \%$ [2]. Persoalan lainnya adalah instabilitas sel surya atau efek Staebler-Wronski [3], yaitu penurunan efisiensi sel surya akibat penyinaran dengan intensitas tinggi. Efek ini

*E-MAIL: yoyok@physics.its.ac.id menyebabkan terjadinya penurunan efisiensi sekitar 10-20\% setelah 3 jam dalam paparan sinar matahari (light soaking).

Kelompok Penelitian Material Sel Surya, yang merupakan bagian dari Laboratorium Bahan Maju, Departemen Fisika, Fakultas IPA, ITS Surabaya, berusaha untuk terlibat, berperan aktif, dan menjadi bagian yang tidak terpisahkan dari seluruh upaya penelitian dunia ini untuk mengatasi krisis energi, melalui penelitian dan pengembangan energi terbarukan, terutama untuk sel surya berbasis material a-Si:H. Sekitar 5 tahun terakhir ini, penelitian tentang sel surya berbasis a-Si:H telah dilakukan dan dikembangkan oleh Kelompok Penelitian Material Sel Surya ini. Efisiensi terbaik yang dihasilkan sekitar 8,86\% [4], capaian sementara yang masih memerlukan kerja keras untuk mengejar efisiensi dari riset NREL yang telah mencapai $13,4 \%$ seperti yang telah disebutkan di atas.

Karena itu upaya untuk memperbaiki dan meningkatkan efisiensi dan stabilitas dari sel surya ini masih terus dilakukan. Ada banyak hal yang masih belum sepenuhya dipahami, dan dimengerti berkaitan dengan efisiensi yang rendah dan terjadinya efek Staebler-Wronski, seperti misalnya, cacat ma- 


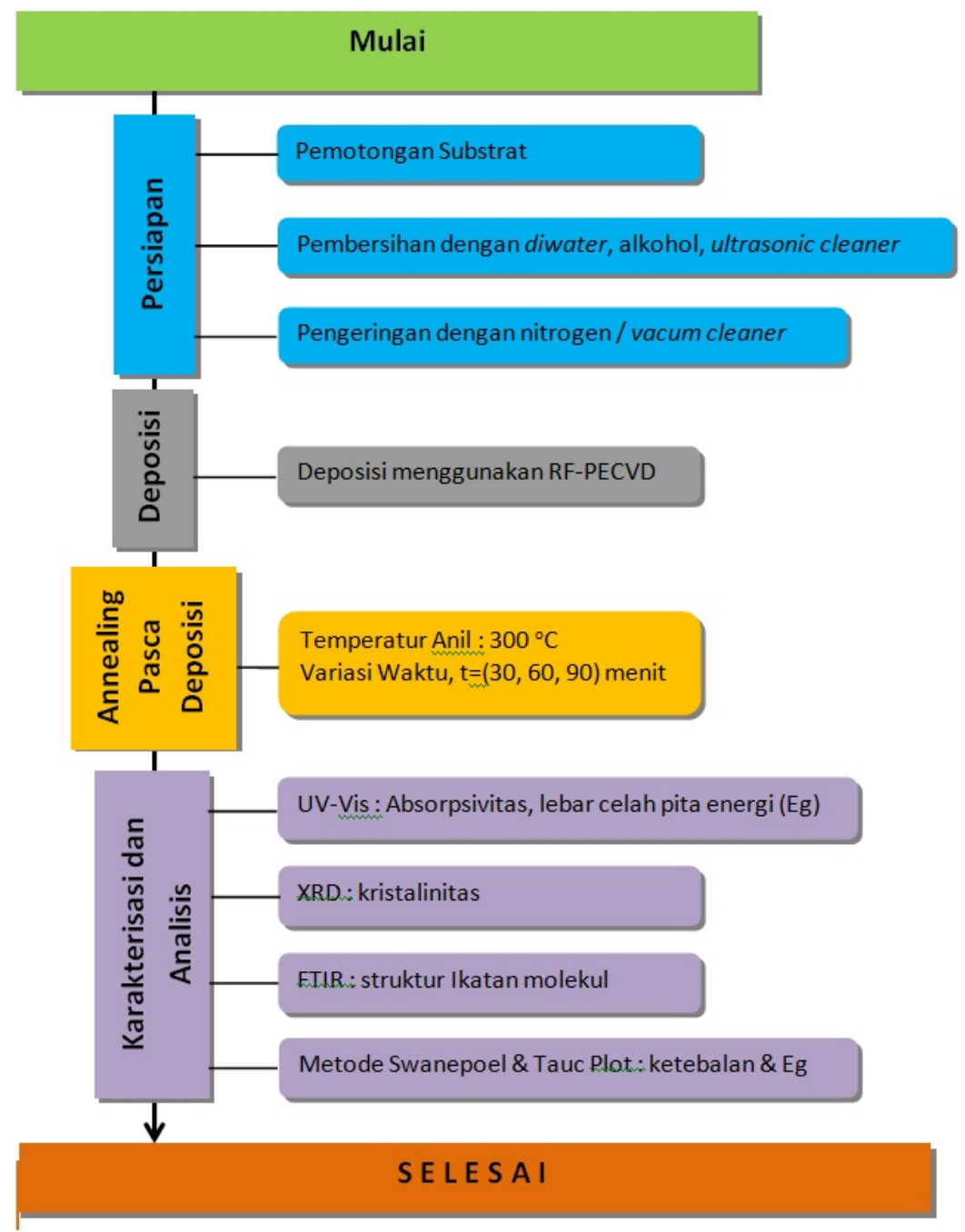

Gambar 1: Diagram alir deposisi dan proses anil lapisan intrinsik 1-layer.

terial (cacat ekor / keadaan terlokalisasi, dan cacat ikatan lepas), struktur atom/molekul, celah pita energi, morfologi permukaan, dan kristalinitas lapisan. Berkaitan dengan hal tersebut, banyak penelitian telah dilakukan oleh kelompok material sel surya, departemen Fisika ITS ini, baik untuk lapisan positip $(\mathrm{P})$ [5], lapisan intrinsik (I) [6, 7], maupun lapisan negatif $(\mathrm{N})[8]$.

Paper ini memfokuskan pada studi pengaruh waktu paparan (light soaking time) pada efek staebler-wronski, dengan menggunakan metode anil. Proses anil yang dilakukan pasca deposisi ini bertujuan untuk mengetahui pengaruh waktu perlakuan panas terhadap lebar celah pita energi, serta hubungannya dengan perubahan fasa. Walaupun telah diketahui bahwa hidrogen adalah pemicu terjadinya keadaan cacat didalam lapisan tipis silikon amorf, namun demikian studi tentang sifat-sifat mendasar dari cacat dan interaksinya dengan hidrogen masih terus dilakukan secara serius dan mendalam oleh banyak peneliti.

\section{METODOLOGI}

Proses deposisi lapisan intrinsik dilakukan dengan menggunakan gas silan $\left(\mathrm{SiH}_{4}\right)$, gas hidrogen $\left(\mathrm{H}_{2}\right)$, dan metode RFPECVD. Parameter deposisi yang digunakan adalah tekanan chamber 2 torr, temperatur substrat $150^{\circ} \mathrm{C}$, daya RF 5 watt, $\mathrm{SiH}_{4}=2,5 \mathrm{sccm}, \mathrm{H}_{2}=90 \mathrm{sccm}$, dan waktu deposisi 60 menit.

Pasca deposisi dilanjutkan dengan melakukan proses anil, yaitu memberikan perlakuan panas pada sampel kemudian ditahan pada temperatur tertentu, dan dibiarkan mendingin pada temperatur ruang. Temperatur anil yang digunakan, $\mathrm{T}_{a}$ $=300^{\circ} \mathrm{C}$, dan variasi lama waktu anil, $\mathrm{t}_{a}=30,60$, dan 90 menit. Secara skematis, diagram alir selengkapnya deposisi dan proses anil lapisan intrinsik 1-lapis berbasis $\mathrm{Si}: \mathrm{H}$ ini, ditunjukkan pada Gambar 1.

Perhitungan tebal lapisan tipis dilakukan dengan menggunakan metode Swanepoel [9], dan lebar celah pita energi ditentukan dengan metode Tauc Plot [10]. 


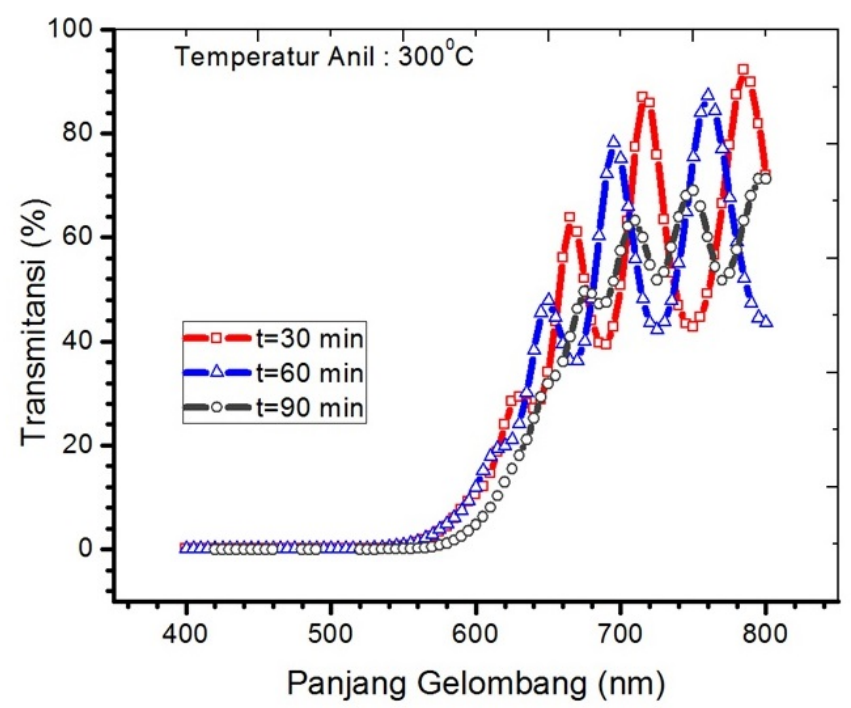

Gambar 2: Transmitansi lapisan tipis a-Si:H sebagai fungsi panjang gelombang untuk waktu anil 30, 60, dan 90 menit, pada temperatur anil $300^{\circ} \mathrm{C}$.

\section{HASIL DAN DISKUSI}

Gambar 2 menunjukkan transmitansi sebagai fungsi panjang gelombang untuk sampel dengan temperatur anil $300^{\circ} \mathrm{C}$, dan variasi waktu anil 30, 60, dan 90 menit. Pada variasi waktu anil 30, 60, dan 90 menit, berturut-turut lapisan meneruskan cahaya maksimal sebesar $92,22 \%$; 87,28\%; dan $69,05 \%$ pada daerah panjang gelombang 500-800 nm. Terlihat bahwa makin lama waktu anil maka transmitansi akan menurun. Penurunan tansmitansi dipastikan tidak disebabkan oleh ketebalan lapisan, karena dari pola frinjinya ketiga lapisan menunjukkan ketebalan yang sama. Penurunan transmitansi diperkirakan disebabkan oleh perubahan kristalinitas, yang mengakibatkan terjadinya perubahan pada lebar celah pita energi lapisan tipis. Hal ini dibuktikan dengan hasil pengukuran kristalinitas, celah pita energi, energi Urbach, dan ukuran partikel, seperti ditunjukkan pada Gambar 3.

Gambar 3(a) menunjukkan bahwa kristalinitas meningkat seiring dengan makin lamanya perlakuan waktu anil, diikuti oleh penurunan celah pita energi pada Gambar 3(b), sehingga transmitansi lapisan menjadi menurun atau absorbansi menjadi meningkat. Ini dapat dipahami karena penurunan lebar celah pita energi mengakibatkan makin bertambah banyaknya energi foton yang bisa terserap oleh elektron untuk bereksitasi dari pita valensi ke pita konduksi.

Kenaikan waktu anil dapat mengakibatkan terlepasnya ikatan hidrogen yang menyebabkan terjadinya peningkatan keadaan terlokalisasi, karena aktivasi ikatan lepas. Energi absorpsi Urbach, digunakan sebagai indikator cacat struktur pada lapisan. Cacat yang paling utama adalah munculnya ikatan lepas. Terlihat pada Gambar 3(c) bahwa pada waktu anil 60 menit, mengakibatkan naiknya energi Urbach, dan turun pada waktu anil 90 menit. Pada umumnya, ketika ikatan lepas pada lapisan meningkat, maka lebar dari celah pita energi akan menurun.

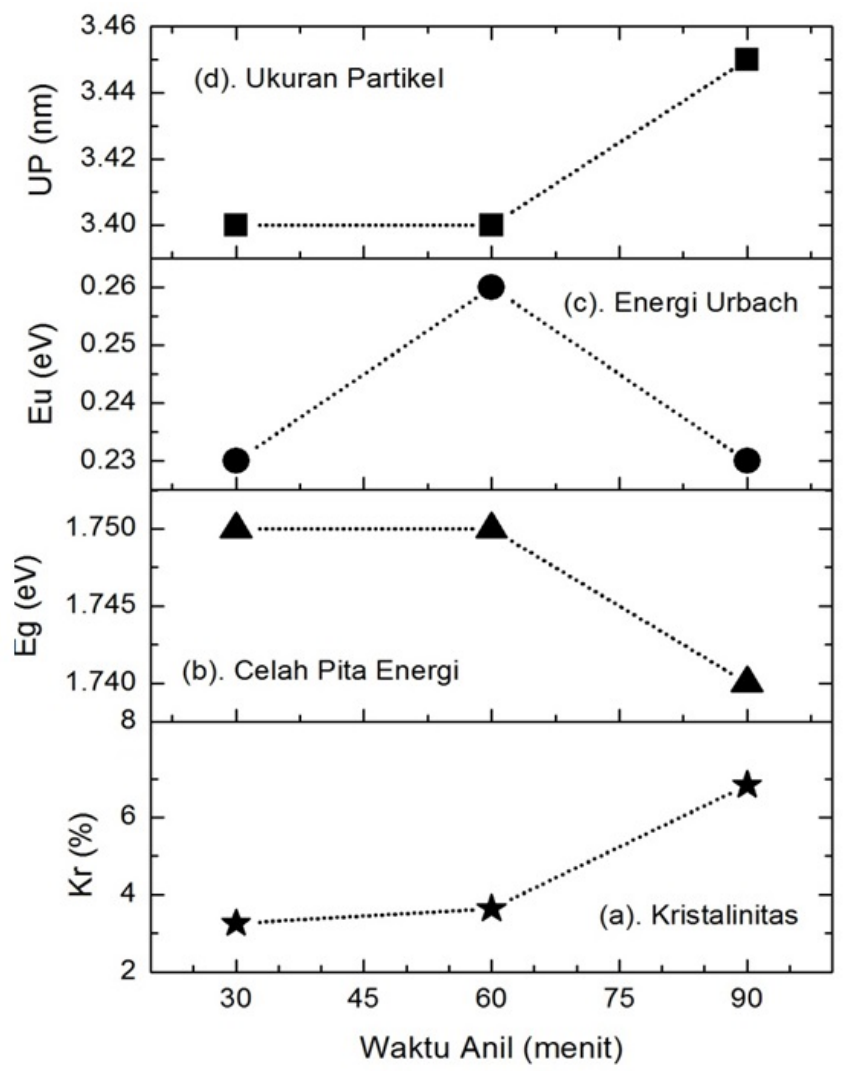

Gambar 3: Kristalinitas (Kr), celah pita energi (Eg), energi Urbach (Eu), dan ukuran partikel (UP) lapisan Si:H dengan waktu anil 30, 60, 90 menit, pada temperatur anil $300^{\circ} \mathrm{C}$.

Ini diperkuat oleh hasil perhitungan perubahan ukuran partikel (grain) sebagai akibat perubahan perlakuan waktu anil yang ditunjukkan pada Gambar 3(d). Pada perlakuan waktu anil 30 menit dan 60 menit, didapatkan lapisan dengan ukuran partikel yang tidak berubah. Karena ukuran partikel tidak berubah dan masih kecil, maka peningkatan energi urbach pada waktu anil 60 menit menjadi kurang signifikan untuk menaikkan lebar celah pita energi. Pengaruh energi Urbach kurang sensitif, jika dibandingkan dengan perubahan ukuran partikel (quantum confinement) [11, 12].

Gambar 4 menunjukkan spektrum absorpsi FTIR dari lapisan Si:H untuk waktu anil 30, 60, dan 90 menit, dengan temperatur anil $300^{\circ} \mathrm{C}$. Terlihat bahwa titik-titik absorpsi senyawa silikon hidrid berada pada bilangan gelombang 887 $\mathrm{cm}^{-1}$ (890/SiH $\mathrm{Si}_{3}$ bending), $1999 \mathrm{~cm}^{-1}$ (2000/SiH stretching), dan $2090 \mathrm{~cm}^{-1}\left(2090 / \mathrm{SiH}_{2}\right.$ stretching $)$. Terjadi peningkatan absorpsi pada titik bilangan gelombang $880 \mathrm{~cm}^{-1}$ terhadap kenaikan waktu anil. Ini mengindikasikan bahwa kerapatan ikatan $\mathrm{SiH}_{3}$ meningkat untuk waktu anil yang lebih lama.

Peningkatan kerapatan $\mathrm{SiH}$ terjadi pada waktu anil 60 menit, dan berkurang pada waktu anil 90 menit, seperti ditunjukkan pada Gambar 5. Kerapatan $\mathrm{SiH}$ dalam lapisan cenderung mengalami penurunan untuk setiap kenaikan waktu anil, kecuali pada variasi waktu 90 menit. Penurunan 


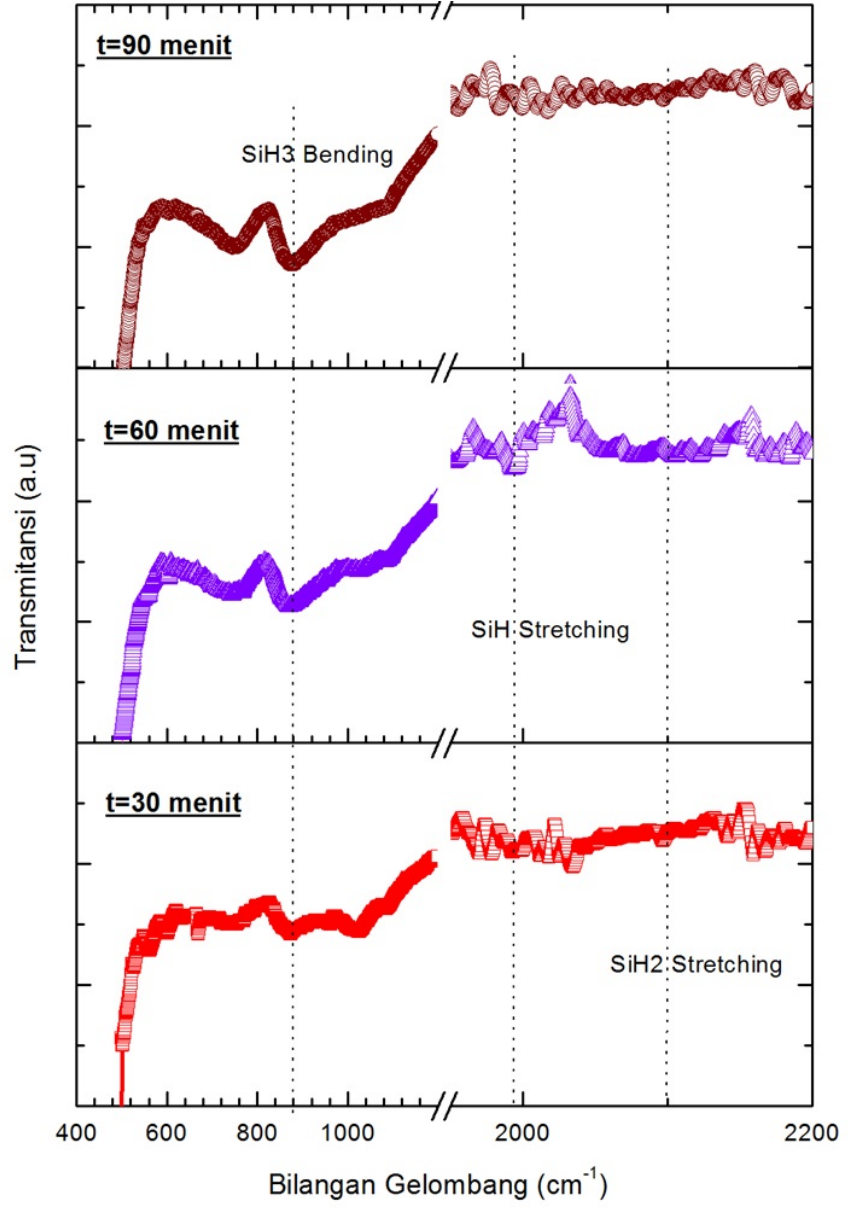

Gambar 4: Spektrum absorpsi infrared (FTIR) lapisan tipis Si:H untuk waktu anil $30,60,90$ menit, dengan temperatur anil $300^{\circ} \mathrm{C}$.

ini dikarenakan ikatan $\mathrm{SiH}$ akan putus ketika dikenai panas, mengakibatkan terbentuknya ikatan lepas pada atom silikon. Ikatan lepas ini merupakan penyebab utama terjadinya efek Staebler-Worski. Pada dasarnya, hasil pengamatan menun- jukkan bahwa penurunan ikatan $\mathrm{SiH}$ pada saat peningkatan waktu anil, juga diikuti oleh peningkatan rapat keadaan dari spin elektron yang tak berpasangan.

\section{SIMPULAN}

Berdasarkan hasil karakterisasi dan analisis yang telah dilakukan dapat disimpulkan bahwa semakin lama waktu anil, umumnya ada kecenderungan untuk menurunkan transmitansi. Penurunan transmitansi diperkirakan disebabkan karena perubahan kristalinitas, celah pita energi, energi Urbach dan ukuran partikel. Kenaikan waktu anil dapat mengakibatkan terlepasnya ikatan hidrogen yang menyebabkan terjadinya peningkatan keadaan terlokalisasi, karena aktivasi ikatan lepas. Kerapatan keadaan dari Si-H berbanding terbalik dengan kerapatan ikatan lepas. Namun, Si-H dan ikatan lepas

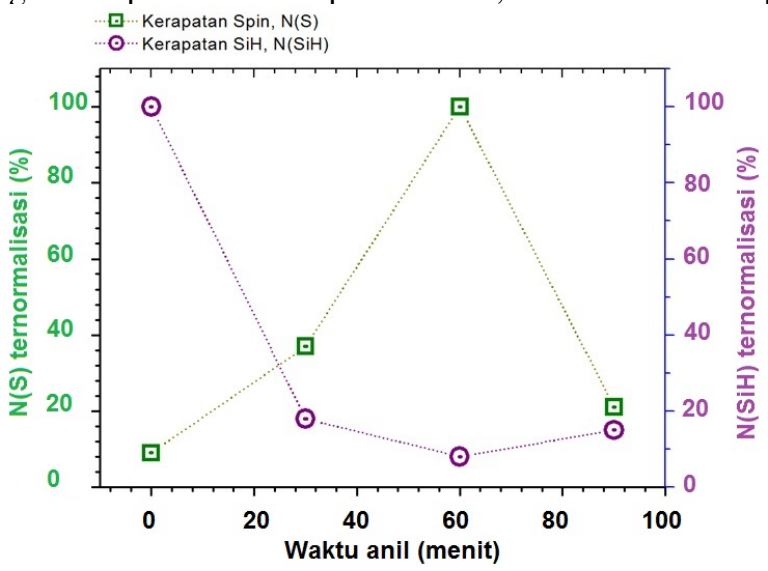

Gambar 5: Rapat keadaan dangling bond (spin elektron) dan $\mathrm{SiH}$ (hidrogen) ternormalisasi, sebagai fungsi waktu anil.

memiliki kaitan interaksi yang rumit. Banyak kemungkinan yang bisa terjadi.
[1] J. Poortmans and V. Arkhipov, Thin Film Solar Cells Fabrication, Characterization and Applications (John Wiley \& Sons Ltd, Chichester, England, 2006).

[2] Best Research-Efficiencies, NREL, http://www.nrel.gov/ ncpv/ images/ efficiency-chart.jpg, 2016.

[3] L. Scholtz, et al., Appl. Phys., 12, 6, 631-638 (2014).

[4] S. Prayogi, Fabrikasi Sel Surya berbasis a-Si:H lapisan Intrinsik Ganda $(P-I x-I y-N)$ dengan PECVD dan Analisis Efisiensinya, Tesis, Institut Teknologi Sepuluh Nopember, Surabaya, 2017.

[5] A. Sholehah, Efek Penambahan gas $\mathrm{CH}_{4}$ dan $\mathrm{H}_{2}$ pada Penumbuhan Lapisan Tipis Silikon Amorf Tipe-P dengan Plasma Enhanced Chemical Vapor Deposition (PECVD), Skripsi, Institut Teknologi Sepuluh Nopember, Surabaya, 2017.

[6] Y. Cahyono, Studi Perubahan Struktur Lapisan Tipis Silikon Amorf Terhidrogenasi (a-Si:H) yang ditumbuhkan dengan Metode PECVD melalui variasi Hydrogen Dilution, Laporan
Penelitian Program Doktor, DIKTI, 2013.

[7] Y. Cahyono, U. Maslakah, F. Muttaqin, and D. Darminto, Reduced energy bandgap of a-Si:H films deposited by PECVD at elevating temperatures, in AIP Conf. Proc., Makasar, Indonesia, 1801, 0200081-6, 2017.

[8] C.F.K. Murti, Penumbuhan Lapisan Tipis Silikon Amorf terhidrogenasi (a-Si:H) Tipe- $\mathrm{N}$ dengan Pengenceran $\mathrm{H}_{2}$ menggunakan Plasma Enhanced Chemical Vapor Deposition (PECVD), Skripsi, Institut Teknologi Sepuluh Nopember, Surabaya, 2017.

[9] N. Pimpabute, et al., Optica Applicata, XLI(1), 257-268 (2011).

[10] Z. Wei, et al., Chin. Phys. B, 24(10), 1081021-6 (2015).

[11] T.W. Kim, et al., Appl. Phys. Lett., 88, 1231021-3 (2006).

[12] J. Mullerova, et al., Advances in Electrical and Electronic Engineering, AEEE, 7(1-2), 369-372 (2008). 